\title{
PENERAPAN PENDEKATAN CONTEXTUAL TEACHING AND LEARNING DENGAN METODE OBSERVASI UNTUK MENINGKATKAN HASIL BELAJAR PADA MATAKULIAH EKOLOGI DASAR
}

\author{
Nur Rokhimah Hanik ${ }^{1}$, Sri Harsono², Anwari Adi Nugroho ${ }^{3}$ \\ 1,2,3 Biology Education FKIP Univet Bantara,Sukoharjo \\ E-mail: nurhanik03@gmail.com
}

DOI: 10.26418/jpmipa.v9i2.26772

\begin{abstract}
In the biology education study program found learning problems about the low learning activities and student learning outcomes. The dominance of female students and the diversity of high school origin causes the classroom climate to be rowdy and the concentration decreases during the lesson. Solution to overcome the problem is with Contextual Teaching and Learning $(C T L)$ approach through observation method applied in Basic Ecology subject.The purpose of this research is to improve student achievement in Basic Ecology subject through learning with CTL approach and observation method. And hope from result of this research is as information material or input that strategy and model of learning with observation method can overcome lack of activity and low result of student learning. This research is an experimental research, with one class experiment of Biology FKIP University of Veteran Bangun Nusantara Sukoharjo second semester of class of 2016/2017 (Basic Ecology subject taker). The data were collected using observation and test sheets. Data analysis technique using $T$ test analysis.From the analysis with $T$ test Paired sample for two groups dependent or paired on pretest and postes data obtained Asymp results. Sig (2-tailled) below 0.05 is 0.00 then Ho is rejected. This means that there are significant differences in learning outcomes before (pretest) and after CTL learning with the method of Observation (postes) in Basic Ecology subject especially on the subject matter of Population and bird diversity. Thus it can be concluded that learning CTL with Observation method can improve student achievement in the subject of Basic Ecology especially the subject of Population or bird diversity.
\end{abstract}

Keywords: CTL approach, Observation method, Basic Ecology subject, Learning Achievement.

Pendidikan yang berkualitas akan mencapai tujuan apabila dalam proses pembelajaran dilaksanakan dengan baik. Proses pembelajaran diperguruan tinggi tercantum dalam Permendikbud tahun 2013 tentang 


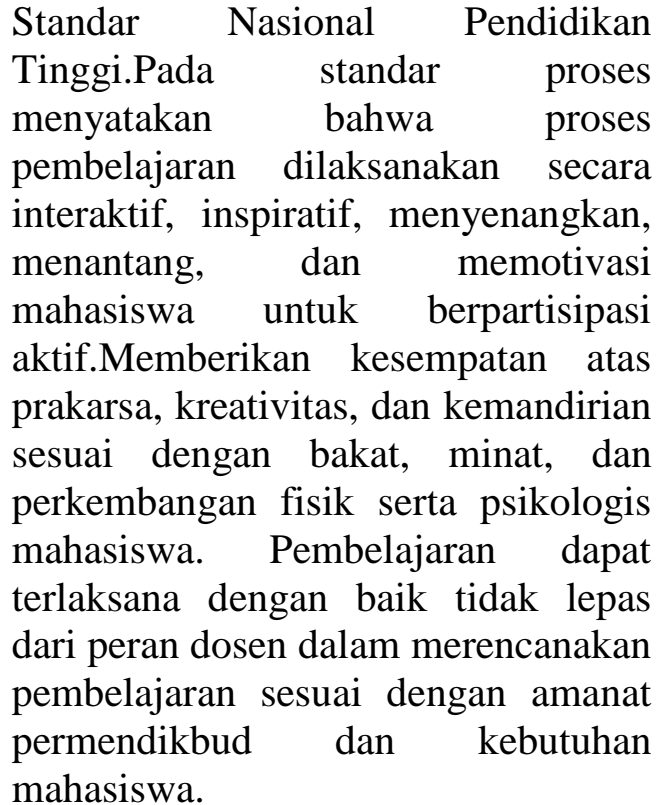

Ada beberapa permasalahan yang berkaitan dengan aktivitas belajar mahasiswa semester II tahun akademik 2016/2017 di Program Studi Pendidikan Biologi Universitas Veteran Bangun Nusantara Sukoharjo. Permasalahan tersebut antara lain; selama proses pembelajaran mata kuliah Sistematika Invertebrata dan Histologi Hewan dengan diskusi informasi maupun dengan pendekatan kooperatif, mahasiswa masih kurang konsentrasi, masih ditemukannya beberapa mahasiswa yang bermain Handphone $(H P)$, sebagian mahasiswa membuat gaduh di dalam kelas, berdiskusi di luar materi pembelajaran. Hal tersebut kemungkinan disebabkan oleh mahasiswa program studi pendidikan Biologi semester II angkatan 2016 berjumlah 13 didominasi oleh mahasiswa putri (10 orang mahasiswa putri dan 3 orang putra) Jumlah mahasiswa yang didominasi oleh putri mengindikasikan banyaknya diskusi atau pembicaraan yang menjurus pada diskusi di luar topik materi pembelajaran. Selain itu dari latar belakang lulusan yang tidak semua dari SMA IPA ( SMK 4 orang dan SMA IPS 2 orang) menyebabkan adanya beberapa mahasiswa yang kesulitan menerima materi Biologi.

Akar permasalahan tersebut di atas kemungkinan karena strategi pembelajaran yang dikembangkan dosen kurang melibatkan aktivitas mahasiswa. Aktivitas pembelajaran di lapangan atau pendekatan Contextual Teaching and Learning (CTL) untuk pembelajar mahasiswa semester II belum dilakukan. Ciri khas pembelajaran Biologi seharusnya menggunakan obyek (media) langsung (berkaitan dengan dunia nyata) agar mahasiswa dapat membentuk konsep sendiri.Dengan kondisi tersebut akhirnya mahasiswa banyak yang kurang memahami materi yang diberikan dan aktivitas belajarnya juga kurang optimal.

Permasalahan aktivitas belajar mahasiswa merupakan permasalahan penting yang perlu diselesaikan. Sardiman (2004: 96) mengungkapkan bahwa aktivitas pembelajaran penting guna mendukung keberhasilan pembelajaran. Sebagai dosen profesional dituntut untuk mampu menguasai berbagai pendekatan/ model/ metode pembelajaran yang sesuai untuk mengatasi permasalahan pembelajaran.

Dari hasil penelitian Syukri Fathudin Achmad Widodo, danWagiran (2005) peran dosen dalam menghadapi pembelajaran ditinjau dari heterogenitas karakteristikmahasiswaadalah:

sebagai fasilitator dan motivator, (2) sebagai inspirator bagi mahasiswa, (3) sebagai manajer yang mengarahkan mahasiswa sesuai dengan kemampuannya, (4) sebagai narasumber, (5) menilai mahasiswa, (6) sebagai pengatur strategi pembelajaran yang aktif dan cerdas.

Lebih lanjut dikatakan bahwa peran dan fungsi dosen sebagai fasilitator 
seiring dengan prinsippembelajaran aktif yang menempatkan mahasiswa sebagai subyek. Hal ini tentunya positif, namun yang perlu dimonitor dan dijaga adalah bagaimana aplikasi di lapangan/perkuliahan.

Pembelajaran

yang

Efektifdalam menghadapi

Heterogenitas

Karakteristik

Mahasiswa tidak dapat dilepaskan dari peran mahasiswa maupun dosen. Beberapa ciri pembelajaran efektif tersebutadalah: (1) mampu mengatasi persoalan yang timbul akibat heterogenitas karakteristik mahasiswa yang bergitu tinggi, (2) pembelajaran berpusat pada mahasiswa, (3) peran dosen sebagai narasumber, fasilitator dan motivator, (4) pembelajaran dengan kelompok kecil heterogen, (5) adanya remedial, (6) mengacu pada prinsip belajar tuntas, dan (7) optimalisasi media pembelajaran. Syukri Fathudin Achmad Widodo, dan Wagiran (2005). Selain itu guru sebagai pembentuk karakter siswa harus mengajar dengan cara mengembangkan kemampuan berfikir kritis (Ayu. 2014 dalam Muhammad Nur Hudha dkk. 2017).

Pada abad 21 ini seorang guru dituntut untuk mampu menguasai dan melatih siswanya lebih kreatif dan inovatif serta unggul dalam afektif, oleh karena itu guru dituntut untuk mampu memahami, menilai dan berpartisipasi dalam menghasilkan pengetahuan baru serta proses yang baru pula. Selain mengajarkan untuk memahami pengetahuan, siswa juga perlu diajarkan mengembangkan kemam-puan pemecahan masalah sehingga siswa terbiasa berfikir kritis secara ilmiah dalam kehidupan sehari-hari (Hudha dkk, 2012 dalam
Muhammad Nur Hudha dkk. 2017). Salah satu solusi yang dipilih dan kemungkinan tepat untuk mengatasi permasalahan pembelajaran tersebut adalah dengan menerapkan pendekatan pembelajaran Contextual Teaching and Learning (CTL).

Menurut Endang Tri Wahyuni, dkk (2012) bahwa pembelajaran kontekstual (Contextual Teaching and $L$ earning) merupakan konsep belajar yang membantu guru mengaitkan antara materi yang diajarkan dengan situasi dunia nyata siswa dan mendorong siswa membuat hubungan antara pengetahuan yang dimilikinya dengan penerapannya dalam kehidupan mereka sebagai anggota keluarga dan masyarakat. Model pembelajaran kontekstual tidak bersifat ekslusif akan tetapi dapat digabung dengan model-model pembalajaran yang lain, misalnya: observasi, penemuan, keterampilan proses, eksperimen, demonstrasi, diskusi, dan lain-lain. Pendekatan kontekstual dapat diimplementasikan dengan baik, dituntut adanya kemampuan guru yang inovatif, kreatif, dinamis, efektif dan efisien guna menciptakan pembelajaran yang kondusif. Guru tidak lagi menjadi satu-satunya nara sumber dalam pembelajaran dan kegiatan telah beralih menjadi siswa sebagai pusat kegiatan pembelajaran serta peran guru hanya sebagai motivator dan fasilitator, maka semangat siswa dapat meningkat dengan menggunakan metode, materi, dan media yang bervariasi.

Menurut Sanjaya (2006). CTL adalah suatu strategi belajar mengajar yangmenekankan kepada proses keterlibatan mahasiswa secara penuh 
untuk dapatmenemukan materi yang dipelajari dan menghubungkannya dengan situasi kehidupannyata sehingga mendorong mahasiswa untuk dapat menerapkannya dalam kehidupanmereka.Dari konsep CTL tersebut ada tiga hal yang harus dipahami:

1. CTLmenekankankepada proses keterlibatan mahasiswa untuk menemukan materi, artinyaproses belajar diorientasikan pada proses pengalaman secara langsung. Proses belajardalam konteks CTL tidak mengharapkan agar mahasiswa hanya menerima materiperkuliahan, akan tetapi proses mencari dan menemukan sendiri pengetahuannya.

2. CTL mendorong agar mahasiswa dapat menemukan hubungan antaramateri yang dipelajari dengan situasi kehidupan nyata, artinya mahasiswa dituntutuntuk dapat menangkap hubungan antara pengalaman belajar dengan kehidupan nyata.Hal ini sangat penting, sebab dengan dapat mengorelasikan materi yang ditemukandengan kehidupan nyata, bukan saja bagi mahasiswa materi itu akan bermakna secarafungsional, akan tetapi materi yang dipelajarinya akan tertanam erat dalam memorimahasiswa , sehingga tidak akan mudah dilupakan.

3. CTL mendorong mahasiswa untuk dapat menerapkannya dalamkehidupan, artinya CTL bukan hanya mengharapkan mahasiswa memahamimateri yang dipelajarinya, akan tetapi bagaimana materi pelajaran itu dapat mewarnaiperilakunya dalam kehidupan sehari-hari. Materi pelajaran dalam konteks CTL bukanuntuk ditumpuk di otak dan kemudian dilupakan, akan tetapi sebagai bekal merekadalam mengarungi kehidupan nyata.

Ciri-ciri secara keseluruhan menggambarkan kondisi mahasiswa yang menjadisubyek belajar dengan metode CTL. Konsep baru yang akan dibelajarkan

hendaknyadipresentasikan dalam kehidupan nyata yang sudah biasa bagi mahasiswa, dandianggap penting dalam kehidupannya kelak. Mahasiswa juga diajak untukmendapatkan dan menganalisis data sendiri sebagaimana mereka dibimbing untukmenemukan suatu konsep penting. Dalam kegiatan tersebut, mahasiswa didoronguntuk berpartisipasi secara aktif untuk meningkatkan kemampuan komunikasinya.

Penerapan CTL dengan metode observasi, maka mahasiswa akan mengkonstruksi atau membangun sendiri pengetahuannya, membuat mahasiswa terlatih untuk bernalar dan berpikir secara kritis melalui kegiatan inquiry atau menemukan sendiri masalah, kebebasan bertanya (questioning), penerapan masyarakat belajar (learning community) yaitu melatih mahasiswa untuk bekerja sama, sharing idea, saling berbagi pengalaman, pengetahuan, saling berkomunikasi sehingga terjadi interaksi yang positif antar mahasiswa dan pada akhirnya mahasiswa terlibat 
secara aktif belajar bersama sama. Hal tersebut di atas sesuai pendapat Prawiradilaga (2009 dalam Rody Putra Sartika dan Ira Lestari 2016) bahwa pembelajaran konstruktivisme menyiapkan siswa untuk membentuk pemahaman dan pola pikir tersendiri. Paradigma baru dalam pembelajaran Sains adalah pembelajaran di amna siswa tidak hanya dituntut untuk lebih banyak mempelajari konsep -konsep dan prinsip-prinsip sains secara verbalistis, hafalan, peengenalan rumus-rumus, dan pengenalan istilahistilah melalui serangkaian latihan secara verbal, namun hendaknya dalam pembelajaran sains, guru lebih banyak memberikan pengalaman kepada siswa untuk lebih mengerti dan membimbing siswa agar dapat menggunakan pengetahuannya dalam kehidupan sehari-hari.

Mata kuliah Ekologi Dasar wajib ditempuh oleh mahasiswa semester II dan merupakan mata kuliah dasar dan prasarat untuk menenpuh mata kuliah Ekologi Tumbuhan dan Ekologi Hewan. Mata kuliah tersebut memiliki muatan materi cukup banyak (Konsep ekologi, Konsep Ekosistem, Konsep energi, Faktor pembatas, Siklus Materi, serta Populasi dan Kominitas). Mata kuliah Ekologi Dasar tidak didukung adanya SKS praktikum, oleh karena itu pendekatan CTL dengan metode observasi ke lapangan dapat digunakan sebagai alternatif pemecahan masalah agar prestasi belajar mahasiswa dapat meningkat.

Pendekatan CLT melalui metode observasi dapat meningkatkan aktivitas belajar mahasiswa dan akhirnya diharapkan prestasi belajarnya juga akan meningkat dikarenakan mahasiswa diajak berhadapan langsung dengan obyek nyata dan terlibat langsung dalam pembentukan konsep sendiri. Adapun keuntungan dari pendekatan CTL adalah:Pembelajaran menjadi lebih bermakana dan riil, artinya siswa dituntut untuk dapat menangkap hubungan antara pengalaman belajar di sekolah dengan kehidupan nyata. Hal ini sangat penting, sebab materi yang dipelajari siswa akan tertanam erat dalam memori siswa, sehingga tidak akan mudah dilupakan..

Pembelajaran lebih produktif dan mampu menumbuhkan penguatan konsep kepada seorang siswa, karena metode pembelajaran CTL menganut aliran konstruktivisme, dimana seorang siswa dituntun untuk menemukan pengetahuannya sendiri. Melalui landasan filosofis konstruktivisme siswa diharapkan belajar melalui " mengalami" bukan "menghapal". (Jhonson dalam Hasnawati (2006). Sedangkan dalam pembelajaran observasi dapat melatih siswa untuk peka terhadap peristiwa atau gejala yang terjadi dalam lingkungannya. Melatih siswa untuk mengambil keputusan yang tepat sesuai dengan nilai-nilai moral yang diperolehdi kelas. Memperluas cakrawala siswa mengenai nilai-nilai moral atau ilmu pengetahuan yang diperoleh didalam kelas dipadukan dengan kenyataan. (Purnomo, 2008). Sedangkan untuk tujuan metode Observasi lebih lanjut Purnomo (2008) mengatakan bahwa siswa akan dapat;1.Memperoleh data atau fakta. 2. Melihat, mengamati dan menghayatinya secara langsung dan nyata mengenai objek tertentu.3. 
Memperoleh kesimpulan dari hasil observasi yang dilakukan.

Dengan penerapan CTL dan metode Observasi pada mata kuliah Ekologi Dasar ini diharapkan dapat memberikan sumbangan pemikiran, serta masukan bagi dosen dan mahasiswa, bahwa untuk mengatasi kurangnya aktivitas dan rendahnya prestasi belajar mahasiswa yang disebabkan oleh jumlah mahasiswa putri yang dominan serta keberagaman karakter mahasiswa sehingga iklim kelas sering gaduh dan kurang konsentrasi saat pembelajaran.

\section{METODE}

Penelitian ini dilakukan di program studi Pendidikan Biologi Fakultas Keguruan dan Ilmu Pendidikan Universitas Veteran Bangun Nusantara. Penelitian dilaksanakan secara bertahap yang secara garis besar dapat dibagi menjadi tiga tahap, yaitu: tahap persiapan, tahap penelitian, tahap penyelesaian. Penelitian dilaksanakan mulai bulan Maret 2017 sampai bulan Juni 2017.

Subjek dalam penelitian adalahmahasiswa program studi pendidikan Biologi Angkatan tahun 2016 (Semester II tahun akademik 2016/2017) sebanyak 13 orang. Penelitian ini merupakan penelitian quasi eksperimen karena variabelvariabel yang berpengaruh tidak dapat dikontrol dengan ketat. Desain yang digunakan dalam penelitian ini adalah One Group Pretest Postest Design dengan menggunakan satu kelas eksperimen (penerapan pendekatan CTL dengan metode Observasi)dengan pemberian pretest dilanjutkan dengan pemberian postest pada kelompok tersebut.

Lokasi pembelajaran dengan metode observasi terdiri dua lokasi yaitu hutan Bromo dan lahan pertanian penduduk Jatidukun kabupaten Karanganyar. Tehnik pengumpulan data dengan test dan observasi. Analisis data menggunakan uji $\mathrm{T}$ ) yang bertujuan untuk mengetahui apakah terdapat perbedaan skor kemampuan kognitif pada kelompok perlakuan sebelum dan sesudah diberikan pembelajaran dengan metode observasi. Tahapan penelitian dapat dilihat pada Gambar 1.

\section{HASIL DAN PEMBAHASAN}

Dari hasil analisis uji prasarat dan data penelitian yang sudah dilakukan dapat dilihat hasilnya pada Tabel 1. Berdasarkan hasil uji prasarat tersebut di atas dapat disimpulkan bahwa uji Normalitas dengan uji Kilmogorov-Smirnov untuk nilai pretest diperoleh signifikansi 0,172 yang berarti nilai signifikansinya lebih dari 0,05 sehingga Ho diterima, kesimpulannya nilai pretest berdistribusi normal. Dan nilai postest diperoleh signifikansi 0,227 yang berarti nilai signifikansinya lebih dari 0,05 sehingga Ho diterima. Kesimpulannya nilai postestberdistribusi normal. 
Tabel 1. Hasil uji normalitas dan uji homogenitas.

\begin{tabular}{llllll}
\hline No & Yang diuji & Jenis uji & Hasil uji & Keputusan & Kesimpulan \\
\hline 1. & Normalitas & Kilmogorov- & Sig.Pretes $=$ & Ho & Data \\
& & Smirnov & $\begin{array}{l}0,172 \\
\text { Sig.Postes }=\end{array}$ & diterima & Normal \\
& & & 0,227 & \\
& & & Sig. 0,667 & Ho & Data \\
\hline 2. & Homogenitas & Levene & diterima & Homogen \\
\hline
\end{tabular}

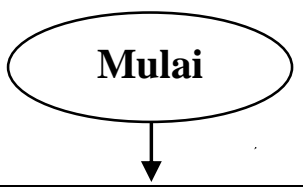

\section{Tahap 1:Observasi permasalahan}

Observasi kelas dan mencari data tentang prestasi belajar/hasil ujian semester gasal th 2016/2017 (semester I) pada mata kuliah Sistematika Invertebrata dan Sistematika Tumbuhan Rendah (STR) dan Invertebrta serta mencari akar permasalahannya.

\section{Tahap 2 :Memilih Solusi}

Memilih strategi pembelajaran yang tepat dengan penerapan pembelajaran CTL melalui metode observasi

\section{Tahap 3:Penerapan Solusi}

1. Menyiapkan perangkat pembelajaran (RPP, LKM, Instr tes, Materi ajar)

2. Merencanakan waktu, tempat pelaksanaan, dan materi kuliah untuk penelitian pembelajaran CTL dengan metode observasi

3. Pelaksanaan pembelajaran (pendekatan CTL) dengan metode observasi

\section{Tahap 4:Evaluasi hasil}

Menganalisis hasil penelitian/ nilai hasil pre test dan pos-test dengan Analisis T test

\section{Tahap 5: Pembahasan}

Membandingkan prestasi belajar sebelum dan sesudah penerapan solusi (metode observasi dalam pembelajaran), dengan memberi justifikasi

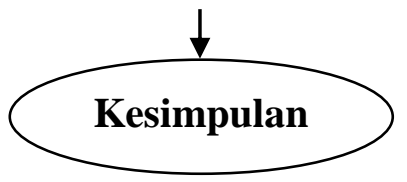

Gambar 1. Tahapan penelitian. 
Hasil uji Levene statistics, didapat signikansi 0,667 yang berarti nilai signikansinya lebih dari 0,05 sehingga Ho diterima, kesimpulannya variansi data homogen. Sehingga data pretestdan postest diketahui berdistribusi normal dan homogen. Hasil Analisi Data (uji T test) nilai pretes dan postes mata kuliah Ekologi Dasar dengan penerapan CTL dan metode Observasi dapat dilihat pada Tabel 2.

Tabel 2. Data hasil pretes dan postes mata kuliah ekologi dasar materi keanekaragaman burung.

\begin{tabular}{cccccc}
\hline Jenis tes & $\begin{array}{c}\text { Jumlah } \\
\text { mhsw }\end{array}$ & $\begin{array}{c}\text { Standar } \\
\text { Deviasi }\end{array}$ & $\begin{array}{c}\text { Nilai } \\
\text { minimum }\end{array}$ & $\begin{array}{c}\text { Nilai } \\
\text { maksimum }\end{array}$ & $\begin{array}{c}\text { Nilai } \\
\text { rata-rata }\end{array}$ \\
\hline Pretes & 13 & 10,36 & 36 & 66 & 54,46 \\
\hline Postes & 13 & 12,67 & 56 & 100 & 89,15 \\
\hline
\end{tabular}

Dari analisis data dengan uji $T$ testPaired sample untuk dua kelompok dependent atau berpasangan pada data pretes dan postes dengan program IBM SPSS Statistik 20 diperoleh hasil Asymp. Sig (2 -tailled) dibawah 0,05 yaitu 0,00 maka Ho ditolak. Hal ini berarti terdapat perbedaan signifikan hasil belajar sebelum (pretes) dan sesudah pembelajaran CTL dengan metode Observasi (postes) pada mata kuliah Ekologi Dasar khususnya tentang materi Populasi dan keanekaragaman burung.

Data hasil penelitian tentang penerapan CTL dengan metode Observasi secara deskriptif Nilai minimum postest ( 56 ) lebih tinggi dari nilai minimum pretest (36) serta nilai maksimum postest (100) juga lebih tinggi dari nilai maksimum pretest (66) sedangkan nilai rata-rata pretest 54,46 lebih tinggi daripada nilai rata-rata postest yaitu sebesar 89,15. Dari hasil analisis data ( $\mathrm{T}$ test)terdapat perbedaan secara signifikan hasil pretest dengan postest, yang berarti pembelajaran CLT dengan Observasi dapat meningkatkan hasil belajar mahasiswa pada mata kuliah Ekologi Dasar khususnya pada materi Populasi dan keanekaragaman burung. Hal tersebut dapat terjadi karena dengan observasi di lingkungan mahasiswa menghadapi objek langsung, sehingga pengetahuannya berkembang dengan baik. Penggunaan pendekatan CTL yang dilakukan bersifat kontekstual atau dihadapkan pada permasalahan yang berkaitan dengan kehidupan sehari-hari populasi burung di lingkungan (hutan dan pekarangan), bagaimana hubungan keragaman dan jumlah burung dengan keragaman jenis tanaman yang ada.

Pengamatan secara kualitatif di lapangan mahasiswa lebih tertarik, lebih senang dan lebih kreatif saat pembelajaran di lingkungan sekitar. Karena semua aspek prestasi belajar mahasiswa memiliki nilai yang lebih baik. Hal tersebut sesuai dengan pendapat (Trianto dalam Endang Tri Wahyuni' dkk, 2012) "konsep belajar dimana guru menghadirkan situasi nyata ke dalam kelas dan mendorong siswa membuat hubungan antara pengetahuan yang dimilikinya dengan penerapannya dalam kehidupan 
sehari-hari." Demikian juga menurut (Shamsid dan Smith, 2006) CTL dapat diterapkan untuk siswa yang belajar di dalam kelas, hal ini dibenarkan dengan praktek siswa yang belajar aktif, belajar dari kehidupan nyata dan belajar dari teman-teman lain.

Dalam

pendekatan

pembelajaran CTL siswa bekerja sama dengan kelompok, saling tukar pendapat, berfikir kritis dan melakukan tindakan. Dalam pembelajaran CTL menekankan mahasiswa untuk aktif dalam kegiatan, mulai dari kegiatan pengorganisasian kelompok atau jenis burung dengan jenis tanaman yang ada dilokasi. Pengamatan objek langsung, mendiskusikan data yang diperoleh, sampai mempresentasikan hasil data yang ditemukan dilakukan mahasiswa. Pendekatan CTL melalui metode observasi lingkungan tersebutbisa sebagai wadah untuk memacu perkembangan pengetahuan mahasiswa. Selain itu Menurut Jhonson dalam Hasnawati (2006), penilaian autentik berfokus pada tujuan, melibatkan pembelajaran secara langsung, mengharuskan membangun keterkaitan dan kerjasama, menanamkan tingkat berpikir yang lebih tinggi.

Pendekatan CTL mempunyai beberapa keuntungan yaitu:Pembelajaran menjadi lebih bermakana dan riil, artinya mahasiswa dituntut untuk dapat menangkap hubungan antara pengalaman belajar di sekolah dengan kehidupan nyata. Hal ini sangat penting, sebab materi yang dipelajari mahasiswa akan tertanam erat dalam memori mahasiswa, sehingga tidak akan mudah dilupakan. Dan pembelajaran lebih produktif dan mampu menumbuhkan penguatan konsep kepada seorang mahasiswa, karena metode pembalajaran CTL menganut aliran konstruktivisme, dimana seorang mahasiswa dituntun untuk menemukan pengetahuannya sendiri. Melalui landasan filosofis konstruktivisme mahasiswa diharapkan belajar melalui " mengalami" bukan "menghapal".

Dalam pembelajaran CTL mahasiswa juga melakukan aktivitas pengamatan langsung maka mahasiswa dapat membentuk konsep sendiri. Ini sesuai dengan pendapat Abimanyu (2008) dan Departemen Pendidikan Nasional (2003) menyatakan bahwa keterlibatan pembelajaran dalam proses pembelajaran dapat berupa keterlibatan peserta didik yang dijelaskan sebagai berikut: Keterlibatan fisik diantaranya melakukan pengukuran, perhitungan, pengumpulan data, atau memperagakan suatu konsep dan lainlain. Keterlibatan mental meliputi: Keterlibatan intelektual, yang dapat berupa mendengarkan informasi dengan cermat, berdiskusi dengan teman sekelas, melakukan pengamatan terhadap sesuatu pengetahuan baru. Keterlibatan intelektual dalam bentuk latihan keterlibatan intektual dalam bentuk latihan keterampilan intelektual seperti menyusun suatu rencana/program, menyatakan gagasan dan sebagainya. Dan keterlibatan emosional dapat berupa penghayatan terhadap perasaan, nilai, sikap dan sebagainya. 
Aktivitas belajar peserta didik merupakan salah satu faktor penting dalam proses pembelajaran. Dimana aktivitas merupakan kegiatan secara berkala yang dilakukan oleh mahasiswasiswa. Keaktifan mahasiswa dalam proses pembelajaran juga akan menyebabkan interaksi yang tinggi antara dosen dengan mahasiswa ataupun dengan mahasiswa itu sendiri. Hal ini akan berdampak pada suasana kelas menjadi kondusif, mahasiswa dapat melibatkan kemampuannya dengan maksimal. Aktivitas yang timbul dari mahasiswa akan berdampak juga terbentuknya pengetahuan dan keterampilan yang akan mengarah pada peningkatan prestasi.

Tingginya hasil belajar atau postes setelah pembelajaran dengan metode Observasi mungkin saja juga terjadi karena ada beberapa kelebihan yang dimiliki olehmetode observasi sehingga hasil belajar yang diperoleh bisa relatif lebih baik. Kelebihan itu antara lain adalah metode observasi sangat bermanfaat bagi pemenuhan rasa ingin tahu siswa sehingga proses pembelajaran memiliki kebermaknaan yang tinggi. Menyajikan media obyek secara nyata tanpa manipulasi.Mudah pelaksanaanya.Siswa akan merasa tertantang.siswa akan memiliki motivasi belajar yang tinggi. Dan memungkinkan pengembangan sifat ilmiah dan menimbulkan semangat ingin tahu siswa. (Purnomo, 2008).

Selain itu dari Purnomo (2008) juga menambahkan bahwa metode observasi merupakan cara belajar mengajar yang dipandang mudah dalam proses belajar mengajar karena pada metode observasi ini akan melatih siswa untuk peka atau gejala yang terjadi dilingkungannya, selain itu juga dapat melatih siswa kritis dalam mengambil keputusan yang tepat serta akan memperluas cakrawala siswa dalam pengetahuan dan wawasan. Jadi hubungannya dengan prestasi adalah ketika siswa peka dengan gejala sekitar, kritis dalam mengambil keputusan yang tepat dan bisa memperluas cakrawala dalam pengetahuan dan wawasan, maka factor-faktor tadi akan memotivasi siswa dalam berprestasi.

Namun demikian dari hasil postes masih ada satu mahasiswa yang memperoleh nilai tes yang yang rendah hal ini kemungkinan disebabkan oleh: Kondisi mahasiswa pada saat proses belajar mengajar atau pada saat mengerjakan postes tidak optimal. Faktor fisiologis siswa sangat mempengaruhi dalam proses belajar. Apalagi dalam penelitian ini tes dilakukan sekali, sehingga kalau kondisi siswa tidak optimal akan memberikan hasil yang kurang baik. Dan faktor minat dan usaha, tidak semua angota kelompok mempunyai minat yang tinggi dan usaha yang sungguh-sungguh dalam mengerjakan tugas dilembar kerja.

\section{SIMPULAN DAN SARAN}

Dari Hasil penelitian dan pembahasan dapat disimpulkan bahwa pada pembelajaran CTL dengan menggunakan metode observasi dapat meningkatkan prestasi belajar mahasiswa pada mata kuliah Ekologi Dasar khususnya materi Populasi dan Keanekaragaman burung. 
Berdasarkan simpulan diatas, maka dapat disarankan sebagai berikut:

1. Pendekatan pembelajaran CTL dengan metode pembelajaran observasi dapat digunakan sebagai upaya untuk meningkatkan hasil belajar mahasiswa pada beberapa mata kuliah dengan materi yang bisa dilaksanakan di lapangan.

2. Dosen sebaiknya menggunakan model pembelajaran yang dapat membangkitkan minat dan motivasi mahasiswa untuk belajar.

\section{DAFTAR PUSTAKA}

Abimanyu, Soli dkk. (2008). Srategi Pembelajaran. Jakarta. Dirjen Pendidikan Tinggi: Depdiknas

Departemen Pendidikan Nasional. (2003). Constextual Teaching and Learning (CTL). Jakarta: Depdiknas.

Endang Tri Wahyuni' dkk.(2012). Pembelajaran Biologi Dengan Pendekatan Contextual Teaching And Learning Melalui Metode Observasi Laboratorium Dan Lingkungan Ditinjau Dari Keingintahuan Dan Kemandirian Belajar Siswa.Jurnal Inkuiri ISSN: 2252-7893, Vol 1, No 1, 19http://jurnal.pasca.uns.ac.id.

Hasnawati. (2006). Pendekatan Contextual Teaching Learning Hubungannya Dengan Evaluasi Pembelajaran. Jurnal Ekonomi \& Pendidikan, Vol 3 No 1, April 2006
Muhammad Nur Hudha, Sudi Dul Aji, Anggita Permatasari, dan Rizki Dian Purnama. 2017. Authenthic Problem Based Learning (Apbl) Untuk Meningkatkan Kemampuan Berpikir Siswa. JPMIPA. Vol. 8. No. 12017

Permendikbud. Tahun (2013). Standar Nasional Pendidikan Tinggi.

Purnomo. (2008). Eksplorasi Biologi. IKIP- PGRI: Semarang.

Sanjaya, W. (2006). Strategi Pembelajaran. Jakarta: Kencana Prenada Media Group.

Sardiman. (2004). Interaksi dan Motivasi Belajar Mengajar. P.T Raja Grafindo Persada: Jakarta.

Shamsid, I. Smith, B. P. 2006. Contextual Teaching and Learning Practices in the Family and Consumer SciencesCurriculum. Journal of Family and Consumer Sciences Education. Vol 24, No 1, 14-25.

Rody Putra Sartika dan Ira Lestari. 2016. Peningkatan Pemahaman Siswa Pada Materi Koloid Menggunakan Pembelajaran Model Siklus Belajar 5E Kelas XI SMAN 2 Pontianak. Jurnal Pendidikan Matematikan dan IPA. Vol. 7 No.2 Juli 2016 
138 Jurnal Pendidikan Matematika dan IPA Vol. 9 No. 2 Juli 2018: 127-138

Syukri Fathudin Achmad Widodo, dan wagiran. 2005. Upaya Dosen Dalam OptimalisasiPembelajaranDitin jau Dari Heterogenitas Karakteristik Mahasiswa.

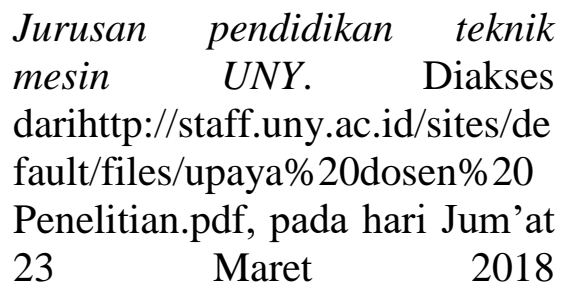

